\title{
The Effect of Job Satisfaction on Turnover Intentions in Star Hotel Semarang
}

\author{
Astadi Pangarso* \\ Faculty of Economics and Business Universitas Telkom, Indonesia
}

\begin{abstract}
This paper investigates the effect of job satisfaction on a turnover intention at the Star Hotel Semarang. We use 113 respondents using a non-probability sampling method at the Star Hotel Semarang. Using linear regression, we found the negative relationship between job satisfaction and turnover, suggesting a problematic association between job satisfaction and turnover intention. Therefore, our result suggests that other factors could be the obstacles to job satisfaction, such as the nature of the employee's work that was not under the job description, too strict supervision by the superiors, and a very long time to obtain the job promotion.
\end{abstract}

Keywords: Job satisfaction, turnover intention, hotel, Semarang, Indonesia

\section{Background}

Dynamic tourism activities are able to revitalize various business sectors that involve a large workforce. Tourism in Indonesia is an industry that provides a sizeable contribution to the country's foreign exchange earnings. In Indonesian Law Number 10 of 2009, Article 1 paragraph 7 regarding tourism explained that: a tourism business is a business that provides goods and/or services for the fulfillment of tourists and the organization of tourism. Many sectors benefit if an area is able to develop tourism, one of which is the hospitality industry.

The hospitality industry is still a promising business for investors and the wider community who want to be involved in this industry as employees or human resources. Human resources in the company in the future will determine the company's success in the future. Progress or setback whether or not the company's vision and mission will be achieved will depend on its human resources. One form of employee behavior is job satisfaction and the desire to move to work (turnover intention), leading to an employee's decision to leave his job.

Robbins and Judge (2015) say that when people talk about worker attitudes, they usually refer to job satisfaction, which explains a positive feeling about work, which results from an evaluation of its characteristics. Someone with a high level of job satisfaction has positive feelings about their work. Conversely, someone with a low level of satisfaction has negative feelings. This can be explained when employees feel dissatisfied will be able to trigger someone's desire to go out and look for another job. This is in line with Huang and $\mathrm{Su}$ (2016) explaining that job satisfaction is a direct cause of an employee in the hospitality industry to make the decision to leave the hotel. Job satisfaction is important for a hotel because employees who are satisfied with their work will tend to promote their hotel as a good and pleasant place to work.

In his research, Saeed et al. (2014) state that job satisfaction has a negative effect on turnover. Employees who are satisfied with their work have low intention to leave. Employees will consider the importance of compatibility between the work results obtained (awards) with the perception of the

\footnotetext{
* Corresponding author at Jl. Telekomunikasi Jl. Terusan Buah Batu, Sukapura, Kec. Dayeuhkolot, Bandung, Jawa Barat 40257. Email: astadipangarso@telkomuniversity.ac.id
} 
results' availability. The more results obtained, he will be more satisfied so that employees' tendency to leave the organization will be smaller (Huang and Su, 2016; Mbah and Ikemefuna, 2012; Tian-Foreman, 2009).

According to Saeed et al. (2014), turnover intentions are the appropriate dependent variable because turnover intentions are closely related to actual turnover. They suggest using turnover intentions rather than actual turnover because actual turnover is more difficult to predict than intentions, such as several external factors that affect turnover behavior.

In this study, we tried to do a similar study in a hotel in the city of Semarang. One of the supervisors we interviewed noted that Hotel Semarang has the most obstacles, including the nature of employee work that is not in accordance with the jobs, oversight by superiors that are too strict, and colleagues' support from one division at work, and promotion that opportunities require more time. Therefore, according to Luthans (2011), this is a dimension of employee job satisfaction. This indicates that Star Hotel Semarang employees have job satisfaction problems by marking the disclosure of these four things.

This research is expected to be one of the reference materials that can add insight, knowledge, and increase understanding of the effect of job satisfaction on the desire to leave the organization and fill research gaps related to the hospitality domain. This study's results are expected to be used as a material consideration for companies, especially Star Hotel Semarang, in managing human resources and providing an overview for the hotel to implement a system that can anticipate employees who wish to leave the organization.

\section{Method}

\section{Econometric Approach}

The approach used in this study is a quantitative method. Sugiyono (2014) argue that quantitative research methods can be interpreted as research methods based on positivism philosophy, used to examine specific populations or samples, sampling techniques are generally carried out randomly, data collection using research instruments, quantitative/statistical data analysis in order to test the hypothesis that has been set. Based on the variables studied, this study is included in the type of causal research.

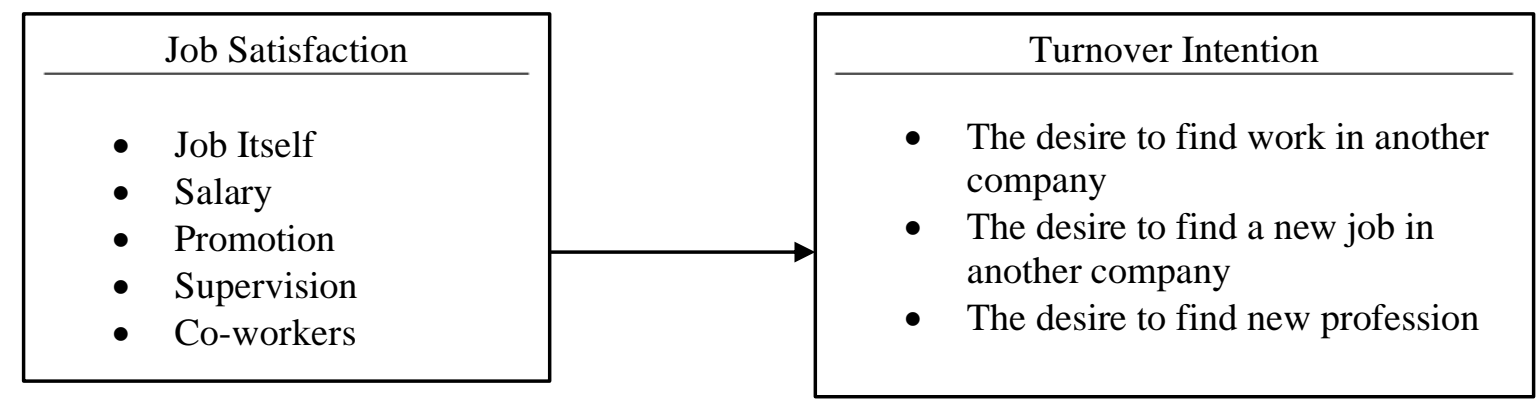

Figure 1. Theoretical Framework

This study will investigate the relationship that occurs between job satisfaction and turnover intention in Semarang Hotels. Basically, job satisfaction is an individual thing because each individual will have a different level of satisfaction in accordance with the values that apply to each individual. The more aspects of work that suit the individual, the higher the level of satisfaction felt. Job satisfaction theory (X) in this study is based on the theory of job satisfaction dimensions. According to Luthans (2011), five job dimensions have been identified to present the most important job characteristics where employees have affective responses. The five dimensions are the job itself, salary, promotion opportunities, supervision, and co-workers. On the other hand, the variable turnover intention can be measured by the following three components: the desire to find a new job in the same field in another company, the desire to find a new job in a different field in another company, the desire to find a new profession. Based on these explanations, we choose variable X from the theory of Luthans (2011) and 
Y variable from the view of Heptanti (2015). To clarify, the framework of thought referred to by researchers in this study can be seen in the above.

\section{Variable Definition}

Table 1 present the definition of each variable we use as well as the item of the questionnaire. We have 31 questions in our questionnaire and all of them could be classified as four dimensions of job satisfaction and three dimensions of turnover intentions.

Table 1. Variables Definition

\begin{tabular}{|c|c|c|c|c|}
\hline Variable & Dimension & Indicator & Item & $\begin{array}{l}\text { Scale } \\
\text { Measurement }\end{array}$ \\
\hline \multirow{16}{*}{$\begin{array}{l}\text { Job } \\
\text { Satisfaction }\end{array}$} & \multirow{4}{*}{ Job Itself } & - Interesting tasks & $1-2$ & Ordinal \\
\hline & & - Opportunity to learn & $3-4$ & Ordinal \\
\hline & & - Responsibility & $5-6$ & Ordinal \\
\hline & & - Opportunity to advance & $7-8$ & Ordinal \\
\hline & \multirow[b]{2}{*}{ Salary } & - $\quad$ Exceeds basic needs & 9 & Ordinal \\
\hline & & $\begin{array}{l}\text { - As a reflection of } \\
\text { appreciation from company }\end{array}$ & $10-11$ & Ordinal \\
\hline & \multirow{2}{*}{ Promotion } & $\begin{array}{l}\text { Promotion on the basis of } \\
\text { performance }\end{array}$ & 12 & Ordinal \\
\hline & & - Promotion of position & 13 & Ordinal \\
\hline & \multirow{3}{*}{ Supervision } & - Concern with employees & 16 & Ordinal \\
\hline & & - Communication & 17 & Ordinal \\
\hline & & - Climate participation & $18-19$ & Ordinal \\
\hline & \multirow{5}{*}{ Co-workers } & - Cooperation & $20-21$ & Ordinal \\
\hline & & - Support & $22-24$ & Ordinal \\
\hline & & - Comfort & $25-27$ & Ordinal \\
\hline & & - Advice & $28-29$ & Ordinal \\
\hline & & - Help & $30-31$ & Ordinal \\
\hline \multirow{7}{*}{$\begin{array}{l}\text { Turnover } \\
\text { Intention }\end{array}$} & \multirow{3}{*}{$\begin{array}{l}\text { Desire to find work } \\
\text { in another company }\end{array}$} & $\begin{array}{l}\text { Intentions to find work in } \\
\text { another company }\end{array}$ & $1-4$ & Ordinal \\
\hline & & $\begin{array}{l}\text { - Looking for information in } \\
\text { other companies }\end{array}$ & $5-6$ & Ordinal \\
\hline & & $\begin{array}{l}\text { - Desire to find work new in } \\
\text { the new company }\end{array}$ & $10-11$ & Ordinal \\
\hline & \multirow{2}{*}{$\begin{array}{l}\text { Desire to find a new } \\
\text { job in a new } \\
\text { company }\end{array}$} & $\begin{array}{l}\text { Intention leave because } \\
\text { there is no progress }\end{array}$ & $7-9$ & Ordinal \\
\hline & & $\begin{array}{l}\text { - Intention to exit after being } \\
\text { accepted at a non-hotel } \\
\text { company }\end{array}$ & $10-11$ & Ordinal \\
\hline & \multirow{2}{*}{$\begin{array}{l}\text { Desire to find a new } \\
\text { profession }\end{array}$} & $\begin{array}{l}\text { With the expertise of many } \\
\text { trying a new profession }\end{array}$ & 12 & Ordinal \\
\hline & & $\begin{array}{l}\text { - Intentions to wish for their } \\
\text { own efforts }\end{array}$ & $13-14$ & Ordinal \\
\hline
\end{tabular}

The measurement scale used in this study is an ordinal scale using the Likert scale method. This technique is done by giving a questionnaire to selected respondents to be answered. The following are alternative responses given by the author: Scale $1=$ strongly disagree (STS); Scale 2 = disagree (TS); Scale 3 = quite agree (CS); Scale $4=$ agree (S); Scale $5=$ strongly agree (SS). 


\section{Data}

We present in Table 2 the turnover of the employee in the Star Hotel Semarang. We could see that most employee leave from Star Hotel Semarang is in April. Furthermore, during the year from January to December, the number of employees leaving more than the number of employees entering. Based on an interview with one of the supervisors in Star Hotel Semarang, we found that that the most obstacles to gain job satisfaction included: the nature of the employee's work that was not under the job description, oversight by superiors that were too strict, the support of colleagues from one division at work, and opportunities for promotion took longer. Therefore, all these obstacles are the same dimension of employee job satisfaction, according to Luthans (2011). This indicates that job satisfaction at the Star Hotel Semarang employees experienced job satisfaction problems by marking the disclosure of these four things.

Table 2. Employee Turnover in Star Hotel Semarang

\begin{tabular}{llll}
\hline Months & Number of Employees & New Hire Employee & Resign Employee \\
\hline January & 113 & 0 & 0 \\
February & 113 & 0 & 0 \\
Marc & 113 & 0 & 0 \\
April & 109 & 0 & 4 \\
May & 109 & 1 & 1 \\
June & 109 & 1 & 1 \\
July & 108 & 0 & 1 \\
August & 108 & 1 & 1 \\
September & 109 & 3 & 2 \\
October & 106 & 0 & 3 \\
November & 106 & 0 & 0 \\
December & 106 & 0 & 0 \\
\hline Total & & 6 & 13 \\
\hline
\end{tabular}

In this study, the population is Star Hotel Semarang employees, amounting to as much as 100 Technical people with non-probability sampling is a saturated sampling. Thus, the number of samples used for this study is the entire population or the number of Star Hotel Semarang employees totaling 100 people. Items examined question declared invalid if $\mathrm{r}$ count $>\mathrm{r}$ table items studied the question say invalid if $r$ count $\leq r$ table. Test the validity of calculated based on 30 initial questionnaires and processed with SPSS software with a confidence level of $5 \%(\alpha=0.05)$. The $r$ is said to be valid if $r>$ 0.361 (Sugiyono, 2012).

\section{Validity testing}

To test the validity can be seen in the correlation coefficient between each statement with a total score. This value is then compared with $r$ table Pearson product-moment (at 0.05 with 2-sided test and $N=30$ ) the importance of the value of $r$ table is 0,361 (Sugiyono, 2012). Table 6 and Table 7 show that all the items on job satisfaction variables $(\mathrm{X})$ and the desire to get out of the organization $(\mathrm{Y})$ are valid.

According to Riduwan (2013), the reliability test was conducted to obtain the accuracy of the data collection tool used. Sugiyono (2012) says that an instrument is said to be reliable if the reliability coefficient of at least 0.6 . 
Table 3. Validity Results of Variable Job Satisfaction (X)

\begin{tabular}{llll}
\hline Variables & Item & Coefficient & Information \\
\hline Job Satisfaction (X) & P1 & 0.755 & valid \\
P2 & 0,535 & valid \\
P3 & 0.674 & valid \\
P4 & 0.801 & valid \\
P5 & 0.670 & valid \\
P6 & 0.615 & valid \\
P7 & 0.507 & valid \\
P8 & 0.613 & valid \\
P9 & 0.535 & valid \\
P10 & 0.674 & valid \\
P11 & 0.670 & valid \\
P12 & 0.615 & valid \\
P13 & 0.507 & valid \\
P14 & 0.613 & valid \\
P15 & 0.660 & valid \\
P16 & 0.737 & valid \\
P17 & 0.565 & valid \\
P18 & 0.755 & valid \\
P19 & 0.801 & valid \\
P20 & 0.587 & valid \\
P21 & 0.463 & valid \\
P22 & 0.777 & valid \\
P23 & 0.647 & valid \\
P24 & 0.755 & valid \\
P25 & 0.503 & valid \\
P26 & 0.660 & valid \\
P27 & 0.737 & valid \\
P28 & 0.565 & valid \\
P29 & 0.801 & valid \\
P30 & 0.587 & valid \\
P31 & 0.777 & valid \\
\hline & &
\end{tabular}

Table 4. Validity Results of Variable Turnover Intention (Y)

\begin{tabular}{llll}
\hline Variables & Item & Coefficient & Information \\
\hline Turnover Intention (Y) & P1 & 0.502 & valid \\
& P2 & 0.792 & valid \\
P3 & 0.731 & valid \\
P4 & 0.676 & valid \\
P5 & 0.763 & valid \\
P6 & 0.794 & valid \\
P7 & 0.784 & valid \\
P8 & 0.763 & valid \\
P9 & 0.755 & valid \\
P10 & 0.660 & valid \\
& P11 & 0.656 & valid \\
P12 & 0.720 & valid \\
& P13 & 0.695 & valid \\
P14 & 0.678 & valid \\
\hline
\end{tabular}

Here are the reliability test results for both variables, namely job satisfaction $(\mathrm{X})$ and the desire to get out of the organization (Y). 
Table 5. Reliability Test Results

\begin{tabular}{lll}
\hline Variables & Cronbach's Alpha & Conclusion \\
\hline Job Satisfaction $(\mathrm{X})$ & 0,960 & reliable \\
Turnover Intention $(\mathrm{Y})$ & 0,940 & reliable \\
\hline
\end{tabular}

\section{Result}

To determine the influence of variable X (job satisfaction) to variable Y (Desire to Exit from Organization), we use simple linear regression analysis. The results of data processing in SPSS 21 is as follows:

Table 6. Linear Regression Analysis

\begin{tabular}{ll}
\hline Variables & Turnover Intention \\
\hline Job Satisfaction & $-0.555^{* * *}$ \\
& $(4.99)$ \\
Constant & $1.175^{* * *}$ \\
& $(2.91)$ \\
\hline R-Square & 0.194 \\
F & $24.9 * * *$ \\
Observations & 106 \\
\hline
\end{tabular}

Notes: $* * *$ denotes significance in $1 \%$.

Based on the results of processing the data in Table 6, it can be formulated in a linear regression model as follows:

$\mathrm{Y}=1,175-0,555 \mathrm{X}$

From the results of the equation, each variable can be interpreted as follows. First, the constant of 1.175 states that if the independent variable $(\mathrm{X})$ is zero, and there is no change, then the desire to get out of the organization will remain valued at $£ 1,175$. Second, the regression coefficient of $X$ is 0.555 . This shows that job satisfaction variables positively affect the desire to get out of the organization; or in other words, if the variable job satisfaction is increased by one unit, then the desire to get out of the organization will increase by 0.555 .

Then, it can be seen F Count is 24.9 with a significance level of 0.000 . Therefore, in the second calculation, that $\mathrm{F}$ count and the level of significance $0.000<0.05$. This means that the job satisfaction variable together significantly influences the dependent variable's desire to leave the organization. Having in mind the influence of job satisfaction on a desire to get out of the organization at the Star Hotel Semarang employee, then the amount of the percentage effect of the two variables can be known through the coefficient of determination. The $\mathrm{R}^{2}$ values obtained ( $\mathrm{R}$ Square) of 0.203 ; if converted into the form of percent, the coefficient of determination obtained for $0.203 \times 100 \%=20.3 \%$. This shows that the influence of job satisfaction on a desire to get out of the organization at the Star Hotel Semarang employees amounted to $20.3 \%$, and the remaining $79.7 \%$ influenced by other factors not examined. Value $20.3 \%$ could not be classified as major or minor on the grounds that studies have examined other factors at the same point of the study, the different variables X, Y are the same, and the same research subject.

\section{Conclusion}

Based on the results simultaneously, there is a significant negative relationship between job satisfaction and turnover intention in Star Hotel Semarang. This result is similar to Luthans (2011), which suggests that there are obstacle factors related to job satisfaction, such as the nature of the employee's work that was not under the job description, oversight by superiors that were too strict, the support of colleagues from one division at work, and opportunities for promotion took longer. The effect of variable job satisfaction $(\mathrm{X})$ to variable a desire to get out of the organization $(\mathrm{Y})$ is seen from the determination coefficient. The value of the coefficient of determination obtained was $20.3 \%$, which 
means that a large influence job satisfaction variable to variable desire to get out of the organization at the Star Hotel Semarang employees by $20.3 \%$ and $79.7 \%$ are influenced by the X, while other factors are not examined in this study. Further research is expected to be investigated by other independent variables outside variables that affect the desire to get out of the organization.

\section{References}

Ghozali, I. (2011), Analisis Multivariat Dengan Menggunakan SPSS, 3rd ed., Badan Penerbit Universitas Semarang, Semarang.

Heptanti, U. (2015), Effect of Job Satisfaction, Organizational Commitment and Turnover Intention Against Compensation at Hotel Quirin Semarang, School of Tourism Economics Indonesia.

Huang, W.R. and Su, C.H. (2016), "The mediating role of job satisfaction in the relationship between job training satisfaction and turnover intentions", Industrial and Commercial Training, Vol. 48 No. 1, pp. 42-52.

Luthans, F. (2011), Organizational Behavior, Mc Graw Hill, Boston.

Mbah, S.E. and Ikemefuna, C.O. (2012), "Job Satisfaction and Employee s' Turnover Intentions in total Nigeria plc . in Lagos State", International Journal of Humanities and Social Science, Vol. 2 No. 14, pp. 275-287.

Riduwan. (2013), How to Use and Interpret the Path Analysis, Alfabeta, Bandung.

Robbins, S. and Judge, T. (2015), Organizational Behavior, Salemba Em., Jakarta.

Saeed, I., Waseem, M., Sikander, S. and Ridwan, M. (2014), "The relationship of Turnover intention with job satisfaction, job performance, Leader member exchange, Emotional intelligence and organizational commitment", International Journal of Learning and Development, Vol. 4 No. 2, available at:https://doi.org/10.5296.

Sugiyono. (2012), Quantitative Research Methods, Qualitative and $R \& D$, Alfabeta, Bandung.

Sugiyono. (2014), Business Research Methods. Bandung, Alfabeta, Bandung.

Tian-Foreman, W. (2009), "Job satisfaction and turnover in the Chinese retail industry", Chinese Management Studies, Vol. 3 No. 4, pp. 356-378. 